ЕГОРОВА Айгюль Николаевна, аспирант кафедры российской политики факультета политологии Московского государственного университета им. М.В. Ломоносова (119991, Россия, г. Москва, Ломоносовский пр-кт, 27, корп. 4 «Шуваловский»; peggy28@таil.ru)

\title{
ИННОВАЦИОННЫЕ ТЕХНОЛОГИИ В ФОРМИРОВАНИИ ПОЛИТИЧЕСКОГО ИМИДЖА РЕГИОНА
}

Аннотация. В статье рассматривается возможность использования инновационных технологий в формировании политического имиджа региона. Автор подчеркивает необходимость использования маркетинговых, информационных технологий, а также концепцию Smart City при формировании политического имиджа региона. Правильно выстроенный имидж является инструментом воздействия на других акторов для сотрудничества и привлечения инвестиций. Регионы России постепенно начинают применять инновационные технологии в брендинге, но этот процесс идет неоднозначно: есть и ошибки, и победы. Автор считает, что эффективность применения инновационных технологий зависит от ряда критериев, таких как гибкость, системность, подконтрольность, рациональность, открытость и обратная связь.

Ключевые слова: инновационные технологии, информационные технологии, маркетинговые технологии, имидж, Smart City, регион

И нновационные технологии территориального брендинга помогают выстраивать и продвигать в коммуникационных каналах конкурентный имидж региона. Брендинг территории представляет собой управляемый процесс, имеющий целью создание яркого, понятного и привлекательного имиджа территории, в первую очередь для жителей региона. Правильно выстроенный имидж региона способен стабилизировать социальную сферу, сплотить жителей.

Сегодня в брендинге регионов применяются маркетинговые, информационные и smart-технологии. Одним из важных аспектов при запуске имиджевой кампании является поиск общих интересов населения региона. Как правило, в зависимости от культурно-географических факторов интересы населения разнятся. Но существуют и универсальные ценностные предпочтения, такие как высокое качество жизни, наличие рабочих мест, благоприятная экология, развитая инфраструктура, политико-экономический потенциал и возможность формирования человеческого капитала [Бельский и др. 2018: 7-8]. Задача брендинга территории - реализовать эти современные ценностные предпочтения людей, а инновационные технологии брендинга призваны помочь быстрее и эффективнее достичь поставленных целей.

В процессе брендинга территории эффективной инновационной технологией является маркетинг, способный наполнить имиджевую кампанию необходимым ресурсом для дальнейшего эффективного продвижения. Маркетинговые технологии в брендинге территорий представляют собой симбиоз управленческих и рекламных инструментов, направленных на привлечение инвестиций и повышение уровня и качества жизни в регионе [Василенко 2017: 97-98].

Если рассматривать такой инструмент маркетинга территории, как реклама, то важно подчеркнуть, что рекламная кампания не должна носить откровенно пропагандистский характер, быть чересчур навязчивой, иначе можно получить обратный эффект. Позиционирование также является эффективным инструментом маркетинга, отличающимся от рекламы правильным управлением информационными потоками с целью моделирования политического образа региона. Позиционирование дает необходимый ресурс для возможности при- 
нятия политических решений и основывается на рейтингах и инвестиционном климате.

Важную роль в брендинге территорий играет информационное сопровождение. Информационные технологии могут быть успешным инструментом брендинга, поскольку СМИ, наряду с органами власти, формируют сегодня нормативные, оценочные и когнитивные компоненты оценки регионального развития. Имидж региона создается с помощью системы коммуникаций, реализующейся при поддержке СМИ. Специалисты, занимающиеся брендингом региона, формируют общественное мнение через СМИ, используя такие стратегии поведения, как побуждение, поддержка, контроль, отвлечение, поддержание коммуникации с обществом. Кроме того, могут использоваться мягкие приемы подачи информации: завышение информационного повода, публикация на смежные темы, «утечка информации», экспертное мнение, интервью со «случайным» прохожим и т.п. [Имидж регионов... 2016: 82-83].

На сегодняшний день при информационном сопровождении брендинга активно используются «новые медиа». Это различные интернет-ресурсы, включающие в себя такие площадки, как Twitter, Facebook, YouTube, ВКонтакте и др. Данные каналы коммуникации создают иллюзию близости публичных фигур к аудиториии, поскольку присутствуют неформальное общение и обратная связь. Глава региона или политический деятель могут моментально донести до большого круга людей информацию, оценить актуальность того или иного вопроса. Непосредственный контакт и возможность обратной коммуникации вызывает доверие и расположение общества, дает возможность быстрой мобилизации [Василенко 2018: 37-39].

Эффективность применения информационных технологий можно рассмотреть на примере республики Татарстан. Власти региона запустили сервисы «Электронный Татарстан», «Открытое правительство», «Народный контроль», «Депутаты Республики Татарстан», «Народный инспектор» и «Народная экспертиза». «Народный инспектор» предполагает активное участие граждан в выявлении фактов нарушения ПДД, приложение «Депутаты Республики Татарстан» обеспечивает удобное взаимодействие с народными представителями в районах, «Народная экспертиза» дает возможность жителям участвовать в разработке региональных законов, обсуждать проекты на начальных стадиях. Информационные продукты просты и доступны для большинства населения, экономят время, средства, вовлекают в социально-политический процесс большее число участников.

Если маркетинговые и информационные технологии брендинга территорий известны уже достаточно давно и успешно используются практически всеми регионами России, то смарт-технологии появились только в последние годы, с началом реализации программы «Цифровая экономика России» (2017 г.). Сегодня понятие «смарт-технологии» означает, прежде всего, «интеллектуальные технологии 21 века, направленные на улучшение уровня и качества жизни граждан, создание современной динамичной системы городских коммуникаций и управления, основанных на развитии цифровых технологий, использование экологичного транспорта (электромобилей и беспилотников), сохранение окружающей среды с помощью безотходных технологий, снижение рисков за счет устранения издержек, связанных с человеческим фактором» [Умный город... 2018: 6-7].

Другими словами, использование смарт-технологий в процессе территориального брендинга становится на наших глазах одним из самых важных направлений в политике современного города - грандиозным технократическим и социально-политическим проектом. Сегодня цифровые технологии 
используются в нашей стране только в крупных мегаполисах - Москве, СанктПетербурге, Казани, Новосибирске и др. Однако в перспективе, с развитием цифровой экономики, они будут более широко использоваться в ребрендинге регионов России.

Таким образом, современная имиджевая стратегия региона сегодня предполагает использование целого комплекса инновационных технологий: она должна быть системной, рациональной и базироваться на симбиозе технических и социокультурных факторов. При применении инновационных технологий в формировании политического имиджа региона необходимо следовать таким критериям, как:

1) проведение мониторинга общественно-политической ситуации в регионе (выявление потенциальных угроз и благоприятных факторов);

2) выявление ожиданий населения региона, а также потенциальных туристов и инвесторов;

3) разработка программы развития с привлечением научного сообщества;

4) широкое обсуждение в Общественной палате региона;

5) формирование гибкой правовой базы и эффективного административного ресурса;

6) корректировка и контроль на всех этапах реализации.

В заключение следует еще раз подчеркнуть: сегодня использование инновационных технологий становится обязательным условием формирования имиджа региона, поскольку они способствуют эффективному брендированию территории.

\section{Список литературы}

Бельский В.Ю., Василенко И.А., Делокаров К.Х. и др. 2018. Стратегия устойчивого развития в контексте политических процессов ХХІ столетия (под ред. А.И. Костина). М.: Изд-во МГУ. 320 с.

Василенко И.А. 2017. Сравнительный анализ современных моделей ребрендинга российских регионов. - Власть. № 2. С. 95-99.

Василенко И.А. 2018. Особенности информационного сопровождения территориального брендинга: модели и технологии. - Власть. Т. 26. № 1. С. 36-40.

Имидж регионов России: инновационные технологии и стратегии ребрендинга (под ред. И.А. Василенко). 2016. М.: Международные отношения. 288 с.

«Умный город» ХХІ века: возможности и риски смарт-технологий в городском ребрендинге (под ред. И.А. Василенко). 2018. М.: Международные отношения. $256 \mathrm{c}$.

\section{INNOVATIVE TECHNOLOGIES IN THE FORMATION OF POLITICAL IMAGE OF A REGION}

Abstract. The article shows the opportunity of innovative technologies application in the formation of the regional political image. The author highlights the necessity of using marketing and informational technologies and Smart City conception in the formation of a political image of a region. Formed in the right way, the regional image is a tool for influence on other actors towards cooperation and investments. The regions of Russia gradually begin to apply innovative technologies in 
branding, but the process is ambiguous, it includes both rise and fall. The author considers that the efficiency of innovative technologies appliance depends on a series of criteria such as flexibility, systemacity, accountability, rationality, openness and feedback.

Keywords: innovative technologies, informational technologies, marketing technologies, political image, Smart City, region

РОЗЕНБЕРГ Валерия Ивановна - аспирант кафедры российской политики факультета политологии Московского государственного университета им. М.В. Ломоносова (119991, Россия, г. Москва, Ломоносовский пр-кт, 27, корп. 4 «Шуваловский»; liorkvalery@gmail.com)

\section{СОЦИОКУЛЬТУРНЫЕ ОСОБЕННОСТИ ПЕРЕГОВОРОВ В АРАБСКИХ СТРАНАХ}

Аннотация. В статье рассматриваются социокультурные особенности переговоров в арабских странах. Автор подчеркивает, что в последние годы роль Ближнего Востока возросла во внешней политике не только Российской Федерации, но и всего мира. Подтверждением тому является значение сирийского конфликта на международной арене и цикл многосторонних международных переговоров и внешнеполитических изменений, которые последовали вслед за ним. По мнению автора, понимание культурных особенностей и логики арабских участников переговорных процессов может снизить конфликтность коммуникации и помочь составлению долгосрочных переговорных стратегий, что будет способствовать достижению необходимых политических соглашений.

Ключевые слова: социокультурные особенности, арабский стиль ведения переговоров, международные переговоры, внешняя политика России, национальные стили ведения переговоров

$\mathrm{B}$ последние несколько лет роль Ближнего Востока в международных отношениях резко возросла. Выгодное расположение этого региона на стыке трех континентов, его интенсивный экономический рост и общая политическая нестабильность на фоне социальных контрастов и эпизодических всплесков вооруженных конфликтов заставляют все мировое сообщество раз за разом обращать свой взгляд на него и принимать все более активное участие в многосторонних коммуникациях с его представителями. Также особое значение имеет тот факт, что Ближний Восток является одним из центров современного терроризма, что представляет огромную угрозу не только для России, но и для всего мира. По этой причине особое внимание в последнее время уделяется сирийскому конфликту: многосторонние длительные переговорные циклы стали причиной глобальных изменений в отношениях многих стран на международной арене.

При оценке сирийского конфликта некоторые аналитики характеризуют его как многослойный пирог, в который вовлечены множество противоречивых и конфликтующих интересов как отдельно взятых государств, так и блоков, группировок, играющих свою не всегда позитивную роль. В их числе, прежде всего, США и НАТО, Турция, монархии Персидского залива, главным образом Саудовская Аравия и Катар, Иран и, наконец, Россия [Ханалиев 2018: 208].

Это плотное сплетение арабских сторон еще раз акцентирует наше внимание на необходимости изучения их национальных специфических коммуникативных особенностей для эффективного представительства на современной международной арене. Если говорить об определении, то национальный стиль на переговорах можно определить как приверженность определенным культурным ценностям, традициям и обычаям, ориентацию на специфические механизмы принятия решений, а также соблюдение определенных правил поведе- 